\title{
Projektowanie partycypacyjne obiektów służby zdrowia z wykorzystaniem wirtualnej rzeczywistości
}

\author{
Piotr Springer \\ https://orcid.org/0000-0001-8874-7229 \\ piotr.springer@put.poznan.pl \\ Instytut Architektury, Urbanistyki i Ochrony Dziedzictwa, Politechnika Poznańska
}

\begin{abstract}
Streszczenie: Artykuł jest próbą zbadania możliwości wykorzystania technologii „Wirtualnej Rzeczywistości” w ramach projektowania partycypacyjnego obiektów architektonicznych realizujących zadania służby zdrowia. Celem niniejszej pracy jest ukonstytuowanie współczesnych narzędzi partycypacyjnych w procesie projektowania zintegrowanego szpitali. W ramach pracy badawczej dokonano krytycznego studium literaturowego oraz analizy istniejących obiektów medycznych, pod kątem wpływu specyfiki funkcji obiektu, na proces jego programowania i projektowania.
\end{abstract}

Słowa kluczowe: wirtualna rzeczywistość, VR, BIM, szpital, służba zdrowia, partycypacja, projektowanie partycypacyjne, architektura

\section{Wprowadzenie}

\section{Zagadnienie badawcze i cel artykułu}

Niniejszy artykuł stanowi syntetyczne przedstawienie efektów pracy prowadzonej przez autora w ramach drugiego etapu projektu badawczego, realizowanego na Wydziale Architektury Politechniki Poznańskiej (Projekt DSMK nr 10/04/DSMK/0 149). Przedmiotowe badania stanowią kontynuację analizy potencjału wykorzystania zaawansowanych technologii w projektowaniu architektonicznym obiektów służby zdrowia.

W pierwszym etapie badań, analizowano związek pomiędzy Wirtualną Rzeczywistością, a projektowaniem w systemach BIM (z języka ang. Building Information Modeling - Modelowanie Informacji o Budynku). Podjęte rozważania dotyczyły koncepcji wykorzystania technologii Virtual Reality nie tylko w zawodowej praktyce projektowej, ale także w edukacji architektonicznej, na szczeblu szkolnictwa wyższego.

Wykonane studium literaturowe oraz kwerendy terenowe (w tym w szczególności wizytacja Szpitala Sourasky Medical Center w Tel Awiwie, opisana w podrozdziale nr 1.2), których celem była analiza in situ funkcjonujących szpitali, wykazały konieczność dalszego zagłębienia się w ogólną problematykę projektowania architektonicznego obiektów służby zdrowia. Dobór narzędzi i modeli projektowych w kontekście omawianej grupy budynków w sposób szczególny wymaga zrozumienia ich funkcji i zależności przestrzennych z niej wynikających. Stąd podjęto decyzję o kontynuacji rozważań w zakresie szeroko pojętego budownictwa szpitalnego, przed przeprowadzeniem dalszych analiz w kontekście wspomagania procesu projektowego zaawansowanymi technologiami. Zagadnieniu podstawowemu - architekturze szpitalnej - poświęcony będzie następny podrozdział, będący także skrótowym przeglądem stanu badań.

Sporządzone w trakcie pierwszego oraz drugiego etapu prowadzonych badań projekty architektoniczne obiektów szpitalnych, wykazały możliwość wykorzystania omawianych technologii w drodze procesu projektowania partycypacyjnego. Partycypacji, w zakresie ogólnym oraz szczegółowo w obszarze kreowania architektury służby zdrowia, poświęcony będzie kolejny rozdział. 
W dalszej części artykułu, na przykładzie fińskiego projektu Evicures, przeprowadzona zostanie analiza implementacji Wirtualnej Rzeczywistości, do projektowania partycypacyjnego. Omówiona zostanie także konfrontacja modeli wspomagania projektowania zaawansowanymi technologiami obrazowania z determinantami formalno-prawnymi warunkującymi przebieg procesu projektowego w Polsce.

Wnioski, z przeprowadzonych prac badawczych, zawarte są w podsumowaniu niniejszego artykułu. Rozważania zwieńczone będą określeniem celu dalszej pracy nad przedmiotowym zagadnieniem.

\section{Problematyka projektowania obiektów służby zdrowia}

Współczesny stan wiedzy w zakresie teorii projektowania architektonicznego obiektów dedykowanych funkcji ochrony zdrowia można uznać jako rozległy. Trafną klasyfikację dostępnych opracowań przeprowadził Michał Tomanek (Tomanek, 2015), rozdzielając dostępną literaturę na trzy grupy.

Pierwszą z nich stanowią opracowana prezentujące poszczególne elementy składowe szpitali, w tym aspekty technologiczne czy funkcjonalne w ramach pojedynczych jednostek organizacyjnych. Można zaobserwować, iż publikacje tego typu należą do najpowszechniejszych w kontekście architektury medycznej.

Druga grupa obejmuje publikacje stanowiące zbiór wytycznych wynikających z przepisów prawa, które regulują sposób kształtowania obiektów medycznych w danym kraju. W kontekście Polski, takiego zestawienia podjął się w ostatnim czasie Robert Idem (Idem, 2014). Tempo modyfikacji przepisów z zakresu budownictwa, zarówno w skali ogólnej jak i szczegółowo, w kontekście budownictwa szpitalnego, jest jednak na tyle szybkie, iż wskazana publikacja obecnie nie spełnia już w pełni swojej roli. W chwili sporządzania niniejszej pracy, nie pojawiła się podobna pozycja, pozostawiając praktykujących architektów w konieczności odszukiwania obowiązujących przepisów w odrębnych źródłach.

Na kolejną grupę publikacji o architekturze medycznej, składają się pozycje podręcznikowe, ujmujące projektowanie szpitali jako całościowy proces i zbiór zależności pomiędzy poszczególnymi elementami funkcjonalnymi budynku. Przez wzgląd na duży wpływ formalno-prawnych determinant projektowych na sposób kształtowania architektury szpitalnej, "opracowania całościowe”, podobnie jak zestawienia aktów prawnych, przypisane są zazwyczaj do systemu prawnego konkretnego Państwa, w którym są wydawane. Rozważając architekturę szpitalną w ramach przepisów i norm polskiego prawa, druga grupa publikacji wydaje się niezwykle uboga.

Na szczególną uwagę w tym kontekście zasługuje publikacja „Projektowanie obiektów służby zdrowia” (Juraszyński et al., 1973). Jednak przez wzgląd na gwałtowny postęp technologii medycznej, w sposób znaczący zmieniła się także metodologia organizacji przestrzeni niezbędnej do wykonywania pracy lekarzy i pielęgniarek. Stąd podręcznik Juraszyńskiego uznawany jest już dziś za anachroniczny.

Próbę uwspółcześnienia idei podręcznika projektowania szpitali z 1973 roku podjęta została w 2015 roku, w ramach wspomnianego wcześniej opracowania Tomanka (Tomanek, 2015). Książka ta opisuje podstawowe schematy funkcjonalno-komunikacyjne w ramach szpitala.

Literatura przedmiotu ujęta całościowo w zakresie źródeł polskojęzycznych jak i pozycji zagranicznych, składa się w zbiór dobrych praktyk i rozwiązań projektowych. Kwestią odrębną pozostaje jednak stopień w jakim wiedza ta jest upowszechniana i wykorzystywana w powszechnej praktyce projektowej.

W kontekście Polski, powszechnie zauważalne są problemy infrastrukturalne stojące w sprzeczności ze stanem nauki w przedmiotowym zakresie oraz zaangażowaniem wyspecjalizowanych jednostek projektowych opracowujących dokumentacje techniczną dla nowych lub modernizowanych szpitali.

Przyczyn błędów w funkcjonowaniu szpitali, związanych z nieprawidłowościami przestrzennymi, można doszukiwać się zatem nie bazie wiedzy teoretycznej, lecz stosunku aktualności wiedzy w zakresie architektury medycznej do nauk medycznych. Medycyna jako jedna z najdynamiczniej rozwijających się dziedzin wiedzy, zdaje się stale wyprzedzać praktykę architektoniczną.

Problem niedostosowania projektowanych budynków medycznych do wymogów współczesnego lecznictwa zauważany jest już od wielu lat, czego przykładem mogą być obserwacje poczynione przy okazji analizy szpitalnych oddziałów łóżkowych w latach siedemdziesiątych (Wojtowicz, 1968).

Wymienione powyżej pozycje, swoim zakresem obejmują w większości wąskie zagadnienia. Niezbędnym dopełnieniem rozważań z zakresu szpitalnictwa jest obserwacja rzeczywistego funkcjonowania obiektów dedykowanych służbie zdrowia, przy okazji której możliwa jest analiza współzależności poszczególnych elementów. 
W ramach prowadzonej pracy badawczej, przeprowadzono kwerendę terenową do Szpitala Sourasky Medical Center w Tel Awiwie (Ryc. 1).

\section{Sourasky Medical Center w Tel Awiwie}

Obserwacje poczynione podczas wizytacji, stały się podstawą do klasyfikacji podstawowych determinant projektowych, mających istotny wpływ na proces projektowania obiektów medycznych. Przegląd literatury z zakresu teorii projektowania szpitali wskazuje na zależność formy budynku od jego funkcji (Bąkowski J., Poplatek J., 2015). Zbiór tychże zależności można określić jako determinanty technologiczne i ergonomiczne. W analizowanym obiekcie w Tel Awiwie, przejawem ww. wytycznej jest zaskakująca szerokość traktów komunikacyjnych (Ryc. 2).

Wysoki udział powierzchni komunikacyjnej, szczególnie w zestawieniu z powszechną w Polsce praktyką projektową w tym zakresie, może wydawać się rozwiązaniem nieekonomicznym. Wbrew pozorom, wymiary ciągów transportowych są rozwiązaniem dogłębnie przemyślanym, także pod kątem optymalizacji kosztów eksploatacji. Istotnym na etapie projektowania obiektu medycznego, jest założenie jego rozwoju w dalszym cyklu życia budynku, przez wzgląd na konieczność stałego dostosowywania przestrzeni zbudowanej, do rozwijającej się technologii medycznej. Korytarze o szerokości znacznie przewyższającej faktyczne potrzeby wynikające z cyrkulacji personelu, pacjentów oraz osób odwiedzających, są odpowiedzią na konieczność okresowej wymiany aparatury diagnostycznej. Opisywane rozwiązanie nie będzie wymagało prowadzenia prac budowlanych, powodujących obstrukcję funkcjonowania obiektu w trakcie aktualizacji aparatury medycznej, co jest zjawiskiem generującym znaczne koszty.

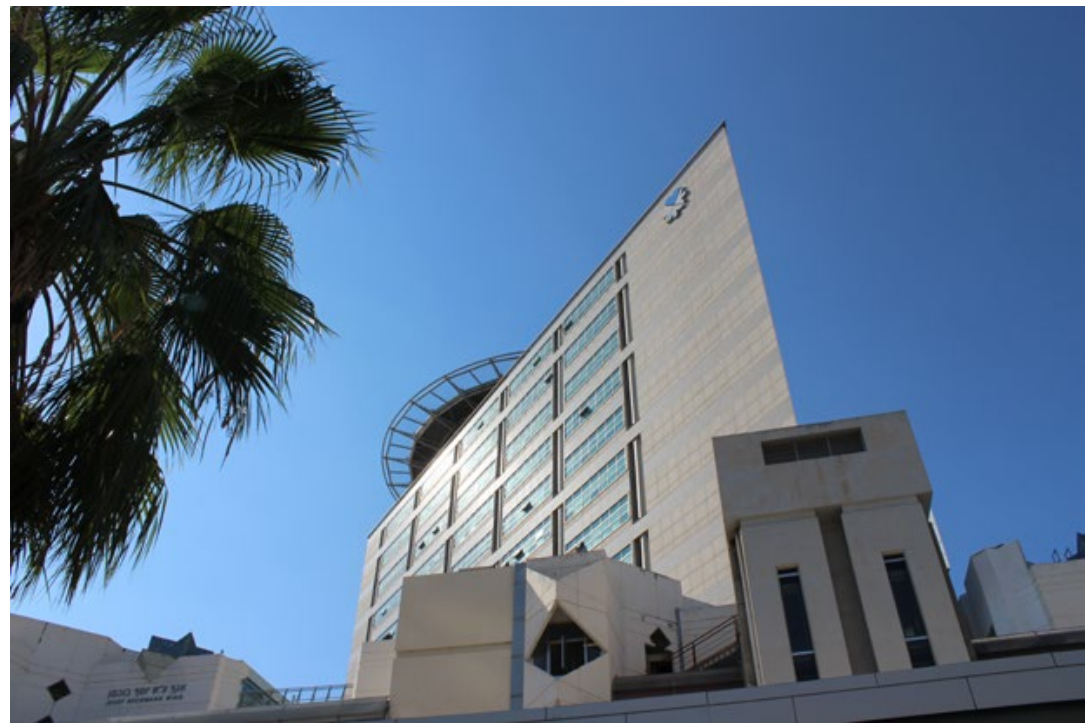

Ryc. 1. Budynek Ichilov Hospital Część składająca się na kompleks Tel Aviv Sourasky Medical Center (Fot. Autor)

Kolejną wyodrębnioną kategorią determinant projektowych, są wytyczne psycho-fizyczne. Odpowiedzią na udowodniony wielokrotnie wpływ przestrzeni zbudowanej na proces rekonwalescencji w przypadku Szpitala Sourasky, jest wprowadzenie do przestrzeni szpitalnych sztuki. Elementy wizualne urozmaicające poczekalnie zmniejszają formalny i technologiczny charakter obiektu (Ryc. 3). Inspirujące w tym kontekście jest także podejście do przestrzeni komunikacyjnej, łączącej dwa budynki i zróżnicowanej wysokości poszczególnych komunikacji.

Dla odciążenia pionowych ciągów komunikacyjnych, połączenie ww. obiektów odbywa się za pomocą ramp o nachyleniu umożliwiającym transport pacjentów na wózkach (Ryc. 4). W ten sposób nastąpiła optymalizacja wykorzystania dźwigów łóżkowych dla transportu pacjentów o wysokim priorytecie, jednocześnie uzyskując niestandardową formę pomostów, nawiązujących do układu krwionośnego. 


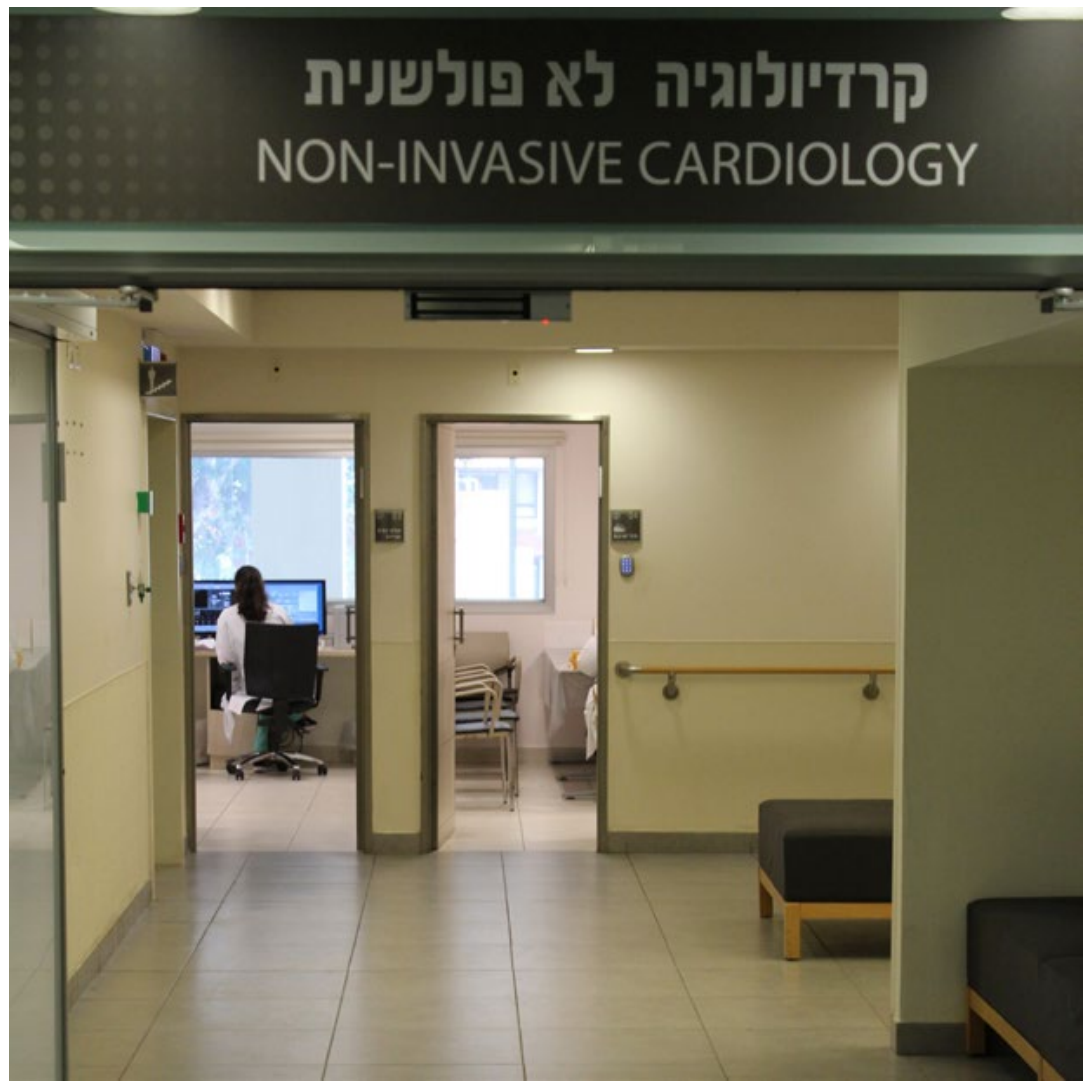

Ryc. 2. Przestrzenie komunikacyjne w Tel Aviv Sourasky Medical Center (Fot. Autor)
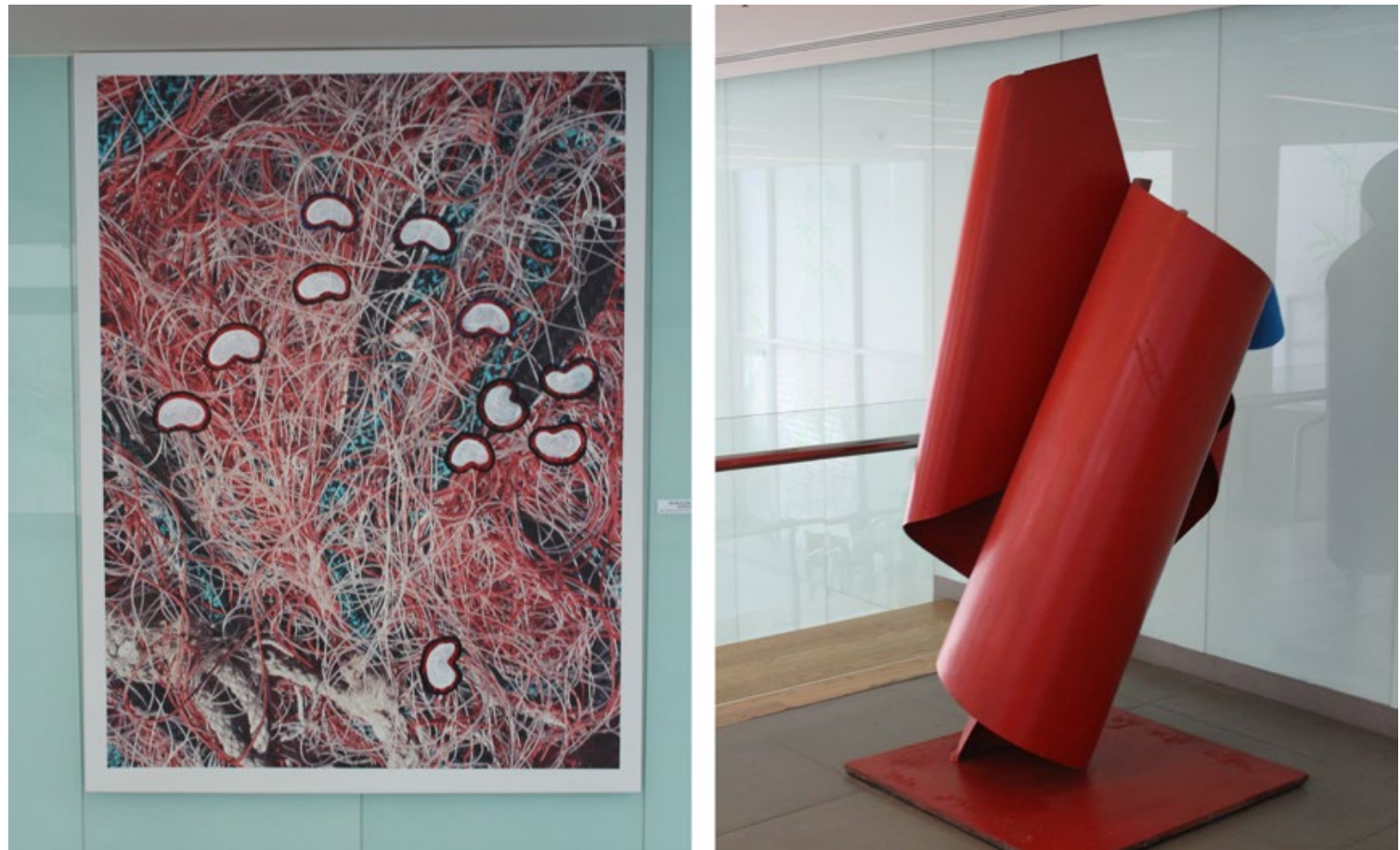

Ryc. 3. Sztuka wizualna w Tel Aviv Sourasky Medical Center (Fot. Autor) 


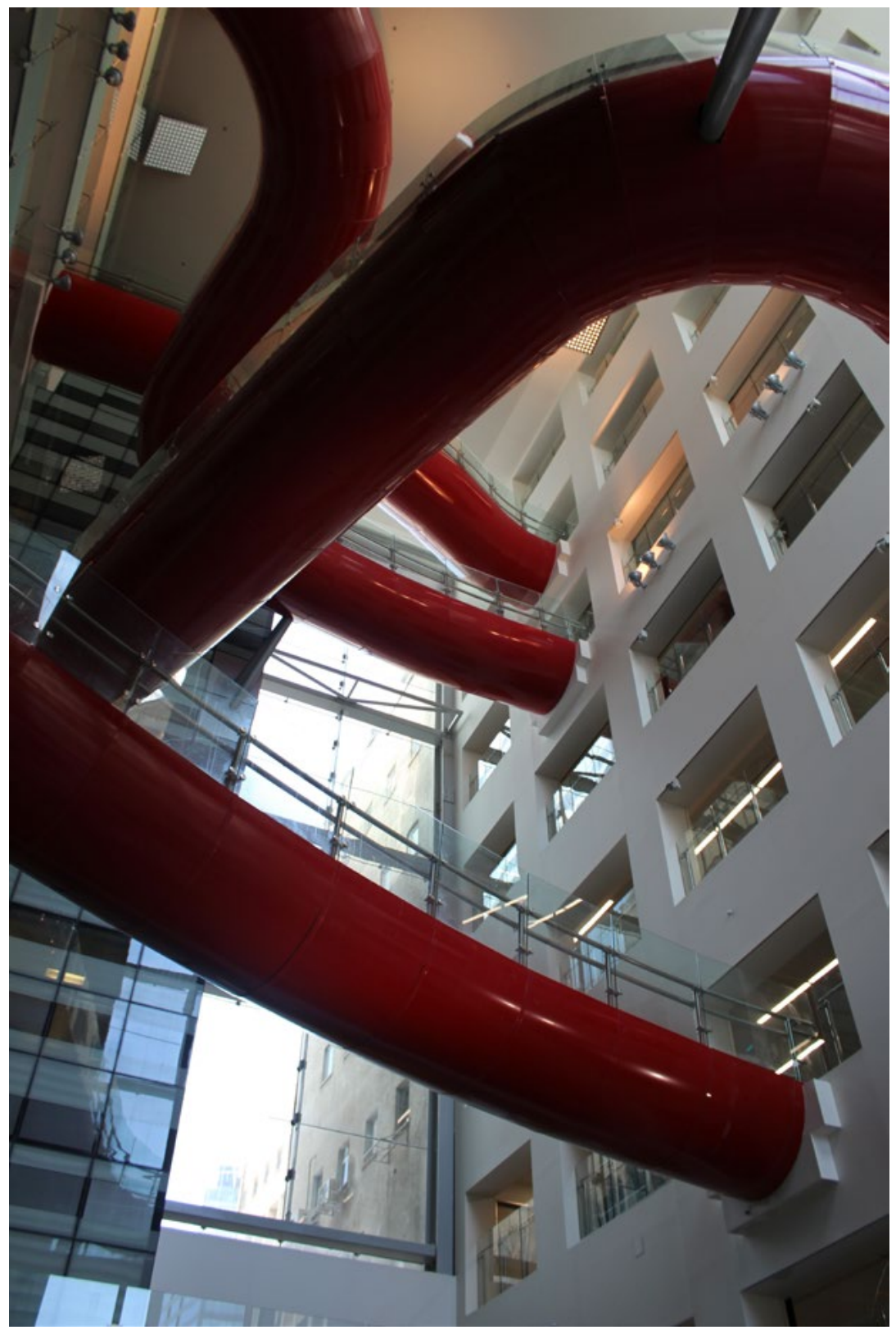

Ryc. 4. Przestrzenie komunikacyjne w Tel Aviv Sourasky Medical Center (Fot. Autor)

W przypadku architektury funkcjonalnej, jaką niewątpliwie jest sztuka projektowania szpitali, sprawność funkcjonowania obiektu zależna jest ściśle od dostosowania jego przestrzeni wewnętrznych do wytycznych technologii determinujących jej funkcję. Opisywany przykład Sourasky Medical Center ukazuje szeroki wachlarz możliwości odpowiedniego i odpowiedzialnego kreowania przestrzeni zbudowanej ze świadomością wymagań wynikających z determinant projektowych, dla tego typu obiektów.

Należy zatem dążyć do odszukania efektywniejszych form prowadzenia samego procesu projektowego, skracających okres jego trwania oraz zapewniających bieżący dostęp projektantów do wytycznych przestrzennych, będących pochodną najaktualniejszej wiedzy medycznej. Odpowiedzią na powyższe poszukiwania może być metodologia projektowania partycypacyjnego. 


\section{Teoretyczny model wprowadzenia partycypacji do procesu projektowego obiektu służby zdrowia}

\section{Projektowanie partycypacyjne}

Projektowanie partycypacyjne stanowi model kreacji, w którym aktywnie biorą udział potencjalni użytkownicy przedmiotowego opracowania. W wydanym pod redakcją Krystyny Pawłowskiej podręczniku technik partycypacyjnych, samo zjawisko projektowania partycypacyjnego określane jest jako sposób uniknięcia konfliktów pomiędzy interesariuszami danego procesu (Pawłowska, 2010).

Partycypacja może odnosić się do wielu dziedzin, w tym m.in. informatyki, grafiki, projektowania krajobrazu, czy szeroko pojętej gospodarki przestrzennej. Włączenie do projektowania użytkowników może mieć miejsce także w architekturze. Liczne przykłady praktycznego wykorzystania omawianej idei oraz rozważania teoretyczne w zakresie implementacji procesów partycypacyjnych do projektowania architektonicznego podnoszone są w publikacjach wybitnego badacza psychologii społecznej, Augustyna Bańki (Bańka, 2018). W powszechnej praktyce projektowej, partycypacja zakorzeniła się zdecydowanie bardziej w projektowaniu urbanistycznym, aniżeli realizacjach w skali architektonicznej.

Wyrazem dysproporcji między pojmowaniem partycypacji w zakresach architektury i urbanistyki, może być program, organizowanej przez Krajowy Instytut Polityki Przestrzennej i Mieszkalnictwa oraz Uniwersytet Jagielloński, międzynarodowej konferencji „Partycypacja dla przestrzeni. Przestrzeń dla partycypacji”, która odbyła się w dniach 14-15 czerwca 2016 r. w Krakowie. Pośród prezentowanych referatów, jedynie autor niniejszego artykułu zaprezentował zagadnienia związane bezpośrednio z wykorzystaniem narzędzi partycypacyjnych w projektowaniu architektonicznym, w tym przypadku konkretnie w zakresie obiektów medycznych. Niniejsza sytuacja skłania do refleksji nad jej przyczyną. Jaki jest powód niskiego stopnia upowszechnienia partycypacji w architekturze?

Odpowiedź na powyższe pytanie może być zakorzeniona w przepisach prawa regulujących sposób wykonywania zawodu architekta w Polsce. Wysoki poziom biurokratyzacji procesu projektowego pozostawia architektom niewielki margines czasu na rozwój warsztatu alternatywnych metod kreowania przestrzeni. Ponadto w obecnym systemie prawnym, partycypacja przejawia się w sposób szczątkowy. Konieczność konsultacji z użytkownikami w definiowaniu przestrzeni określona jest jedynie w zakresie regulacji związanych $z$ planowaniem przestrzennym Na podstawie Ustawy z dnia 27 marca 2003 r. o planowaniu i zagospodarowaniu przestrzennym, organy samorządowe zobowiązane są do przeprowadzenia konsultacji społecznych w trakcie sporządzania studiów uwarunkowań i kierunków rozwoju przestrzennego czy miejscowych planów zagospodarowania przestrzennego. Wprowadzona do systemu prawnego partycypacja pozbawiona jest jednak szczegółowych wytycznych określających sposób organizowania wspomnianych powyżej konsultacji z mieszkańcami objętych opracowaniem obszarów (Starzyk, 2015).

Kolejny obraz pozycji modelu partycypacji w powszechnej praktyce projektowej, rysuje się przy próbie analizy programów nauczania polskich Wydziałów Architektury. Zagadnienia integracji użytkowników w definiowaniu przestrzeni przejawiają się analogicznie do ich występowania w przepisach prawa, tj. zazwyczaj w ramach urbanistyki czy planowania przestrzennego. Prawdziwą zatem wydaje się teza, mówiąca o braku systemowego ukonstytuowania projektowania partycypacyjnego w nauczaniu architektonicznym, na poziomie szkolnictwa wyższego.

Dogłębna analiza przyczyn, z których wynika stosunkowo niskie zainteresowanie środowiska architektonicznego metodami partycypacyjnymi, mogłoby jednak stanowić temat odrębnej pracy badawczej.

\section{Partycypacja w projektowaniu architektonicznym szpitali}

Złożoność i odrębność funkcjonalno-komunikacyjna poszczególnych jednostek organizacyjnych wewnątrz szpitala uniemożliwia zunifikowanie sposobu organizacji tychże przestrzeni. Stąd zasadne wydaje się także osobne rozpatrywanie metodologii projektowania w zakresach przestrzeni w znaczący sposób różniących się od siebie. Przykładowo rozdzielnie należy traktować obszar rejestracji pacjentów (miejsce, w którym paradygmatem projektowym będzie stworzenie przyjaznej nowoprzybyłemu pacjentowi przestrzeni) od jednostek zabiegowych, 
(w którym wiodącym aspektem będzie wypadkowa ergonomii pracy personelu medycznego oraz wymagań kształtowanych przez współczesną technologię medyczną).

Różnice $w$ funkcjonowaniu poszczególnych jednostek organizacyjnych szpitala przekładają się także na brak możliwości utworzenia spójnego modelu partycypacyjnego dla tych obszarów. Dla oddziałów łóżkowych uzasadniony wydaje się udział w procesie projektowania partycypacyjnego pacjentów, osób odwiedzających, a także personelu. W innym przypadku: dla bloków operacyjnych rozważana będzie w głównym stopniu partycypacja z personelem (osoby odwiedzające nie mają na blok operacyjny wstępu, natomiast pacjenci po przeprowadzonej premedykacji mają w dużym stopniu ograniczony stopień odbierania bodźców środowiska zbudowanego). Jeszcze inne podejście należy przyjąć w programowaniu rozległych przestrzeni technicznych czy magazynowych stanowiących przestrzenie funkcjonowania personelu technicznego oraz logistycznego.

Po wstępnym określeniu jednostek organizacyjnych struktury szpitalnej, w których logicznym byłoby zastosowanie projektowania partycypacyjnego, kolejnym krokiem w drodze implementacji omawianej metodologii do praktyki projektowej jest odszukanie determinant określających podstawowe zalecenia dla sposobu i metodologii współtworzenia projektu przez wszystkich interesariuszy.

Nakreślony w poprzednim podrozdziale niniejszej publikacji kontekst formalno-prawny partycypacji w projektowaniu, nie określając warunków prowadzenia konsultacji z użytkownikami w ramach projektowanych, bądź rozbudowywanych budynków. Tym bardziej nie stanowi wsparcia w przeprowadzeniu partycypacji w kontekście obiektów złożonych funkcjonalnie takich jak szpital.

Objętość dostępnej literatury przedmiotu, ściśle w zakresie partycypacji dla planowania architektury medycznej, na tle ogólnego zagadnienia projektowania szpitali zdaje się być stosunkowo uboga. Dostępne są pojedyncze rozważania w formie artykułów czy referatów konferencyjnych (Geuens et al., 2018; Rothmann et al., 2016). Zdecydowanie brakuje w literaturze pozycji podręcznikowych, ujmujących partycypację jako całościową metodę w programowani i projektowaniu szpitali.

Wnioskiem z analizy aktualnego stanu badań, jest konieczność wyodrębnienia nowych narzędzi partycypacyjnych, indywidualnie dla potrzeb architektury służby zdrowia.

\section{Wspomaganie projektowania partycypacyjnego technologią wirtualnej rzeczywistości}

W szpitalach, przestrzeń będzie miała bezpośredni wpływ na sposób wykonywania procedur medycznych, a tym samym na zdrowie i życie pacjentów procedowanych obiektów medycznych. Podstawowym czynnikiem przemawiającym za wprowadzeniem partycypacji do projektowania szpitali jest możliwość zwiększenia stopnia dostosowania opracowywanego obiektu, do wymogów współczesnej medycyny, tym samym poprawy jakości świadczenia usług w omawianych obiektach.

Aby zamierzony skutek miał miejsce, należy zmaksymalizować skuteczność komunikacji pomiędzy interesariuszami procesu projektowego. Biorąc pod uwagę fakt uczestniczenia w procesie projektowym grup niebędących zawodowo związanych z projektowaniem architektonicznym, jedną z podstawowych barier komunikacyjnych będzie sposób wizualizacji planowanych rozwiązań projektowych.

Na tej samej zasadzie w myśl, której nie należy oczekiwać od architekta rozległej wiedz na temat medycyny, irracjonalnym byłoby wymaganie od użytkowników projektowanego szpitala, przykładowo grupy lekarzy czy pielęgniarek, płynności w odczytywaniu rysunków technicznych. Natomiast okazywanie proponowanych rozwiązań projektowych w formie płaskich reprezentacji modelu trójwymiarowego, może być niewystarczające dla przeanalizowania funkcjonalności obrazowanej przestrzeni w kontekście ergonomii użytkowania technologii medycznej. Odpowiedzią na powyższe zagadnienia może stać się technologia Wirtualnej Rzeczywistości (VR), dająca możliwość szerszego przebadania zależności przestrzennych, w wysokim stopniu immersji w projektowanym środowisku, już na etapie projektu koncepcyjnego.

Ciekawym przykładem praktycznego zastosowania VR w projektowaniu partycypacyjnym szpitali jest prowadzony w latach 2014 - 2016 fiński projekt Evicures Jego założeniem było stworzenie przyjaznych użytkownikowi przestrzeni oddziałów anestezjologii i intensywnej opieki medycznej (OIOM) Seinäjoki Central Hospital. Przy wykorzystaniu oprogramowania wspierającego komputerowe kreślenie (CAD) sporządzono w środowisku VR model projektowanego oddziału. W kolejnym etapie grupa projektowa przygotowała dla personelu istniejącej 
części szpitala grę komputerową opartą o obrazowanie w Wirtualnej Rzeczywistości. Lekarze oraz pielęgniarki mogli poruszać się w wirtualnych przestrzeniach opracowywanego OIOMu i doświadczać w nich interaktywnych symulacji ich codziennej pracy. (Nykänen E. et al., 2016).

Obserwacja interakcji użytkowników z wirtualną przestrzenią poczyniona przez grupę badawczą, pozwoliła zaprojektować ergonomiczną przestrzeń pracy, jednocześnie zwiększając poziom satysfakcji personelu medycznego, odczuwany przy realizacji obowiązków służbowych.

\section{Podsumowanie}

Podejmując próbę zdefiniowania konkretnych metod warsztatowych partycypacji dla kreowania nowego lub rozbudowy istniejącego szpitala, należy pochylić się nad problemem wynikającym z samej natury włączania do procesu projektowego jednostek czy grup interesariuszy, niebędących zawodowo związanych z praktyką architektoniczną. Takim zagadnieniem będą z pewnością bariery komunikacyjne, pomiędzy projektantem, a potencjalnymi użytkownikami końcowymi. Przyczyną występowania trudności w porozumieniu, może być problematyka obrazowania propozycji przestrzennych dla danej inwestycji.

Architekt, dysponując wachlarzem adekwatnych umiejętności, już od początkowej fazy projektu stara się przekazywać interesariuszom zapis graficzny prezentujący kreowaną przestrzeń. W przypadku błędnego odczytu materiałów graficznych przez różne grupy interesariuszy, którym materiały projektowe zostały udostępnione do zaopiniowania, partycypacja zamiast być narzędziem mającym zminimalizować ryzyko wystąpienia konfliktu, stanie się jego katalizatorem.

W ramach projektu Evicures, jako skuteczny określono sposób wizualizacji zamierzeń projektowych, wykorzystujący technologię Wirtualnej Rzeczywistości. Realizację architektoniczną na bazie omawianego projektu zakończono w 2018 roku. Ostateczna ocena proponowanego przez Finów rozwiązania możliwa będzie po dogłębnym przeanalizowaniu funkcjonowania przedmiotowego oddziały szpitalnego oraz zestawieniu parametrów definiujących efektywność jednostki z oddziałami projektowanymi bez użycia partycypacji.

Przebadanie możliwości implementacji podobnych rozwiązań w warunkach procedowanych w Polsce inwestycji z zakresu ochrony zdrowia, wymaga przede wszystkim ugruntowania pozycji samej partycypacji w procesach inwestycyjnych.

Dla popularyzacji omawianych zagadnień kluczowym jest zwiększenie świadomości potencjału innowacyjnych technologii w partycypacji projektowej, pośród zarówno architektów, jak i jednostek finansujących i zarządzających służbą zdrowia. Dalszy rozwój badań w przedmiotowym zakresie powinien skutkować utworzeniem rozwiązań systemowych, dążących do ukonstytuowania samej partycypacji jako jednego z podstawowych modeli kreowania architektury medycznej.

Podsumowaniem może być stwierdzenie, iż powszechne wprowadzenie partycypacji w inwestycjach ochrony zdrowia w Polsce, wymaga partycypacji w ramach wspólnych wysiłków: ustawodawcy, środowiska akademickiego, środowiska lekarskiego oraz architektonicznego.

\section{Literatura}

[1] Bańka A., Psychologia środowiskowa jakości życia i innowacji społecznych, Stowarzyszenie Psychologia i Architektura, Uniwersytet SWPS, Poznań-Katowice 2018.

[2] Bąkowski J., Poplatek J., Szpital - forma i funkcja, [w:] red. Gębczyńska-Janowicz A., Idem R., Architektura służby zdrowia. Problematyka projektowa, Wydawnictwo Politechniki Gdańskiej, Gdańsk 2015, s. 11-28.

[3] Geuens J. et al., Turning tables: a structured focus group method to remediate unequal power during participatory design in health care, https://www.researchgate.net/publication/327122614_Turning_tables_a_structured_focus_group_method_ to_remediate_unequal_power_during_participatory_design_in_health_care [21.12.2018].

[4] Idem R., Architektura służby zdrowia. Wybór przepisów i literatury przedmiotu, Wydawnictwo Politechniki Gdańskiej, Gdańsk 2014.

[5] Juraszyński J., Nitsch A., Porębowicz S., Radwański Z., Projektowanie obiektów służby zdrowia, Wydawnictwo Arkady, Warszawa 1973. 
[6] Nykänen E. (red.) et al., A user-oriented, evidence-based design project of the first Finnish single room ICU. Result of EVICURES project, 2016, http://www.epshp.fi/evicures_hanke/tietoa_hankkeesta/evicures_project_in_english [21.12.2018].

[7] Pawłowska K. (red.), Zanim Wybuchnie Konflikt. Idea i metody partycypacji społecznej w ochronie krajobrazu i kształtowaniu przestrzeni, Tom: A: Dlaczego?, Fundacja partnerstwo dla środowiska, Kraków 2010.

[8] Rothmann M., Danbjørg D.B., Jensen C.M., Clemensen J., Participatory design in health care: participation, power and knowledge, 2016, https://www.researchgate.net/publication/305727950_Participatory_design_in_health_care_participation_power_and_knowledge/citations [21.12.2018].

[9] Starzyk K., Uwarunkowania prawne partycypacji obywatelskiej w Polsce. Pracownia Badań i Innowacji Społecznych Stocznia, 2015, https://partycypacjaobywatelska.pl/wp-content/uploads/2015/07/partycypacja_regulacje-prawne.pdf [21.12.2018].

[10] Tomanek M., Technologia medyczna w projektowaniu obiektów szpitalnych, Wydawnictwo Śląsk, Katowice 2015.

[11] Wojtowicz R., Modernizacja przestrzenna oddziatów tóżkowych nowych szpitali w Polsce w wybranych aspektach ergonomicznych, Wydawnictwo Uczelniane Politechniki Poznańskiej, Poznań 1968.

\title{
Participatory design of healthcare facilities using virtual reality
}

\begin{abstract}
This paper is an attempt to explore the possibilities of using Virtual Reality within participatory design of healthcare facilities. The aim of this work is to determine fields in which technologically advanced participatory design tools may improve integrated design. As a part of research, a scientific literature review and an analysis of existing medical facilities have been made, especially in the context of influence that building function have on the process of its programming and designing.
\end{abstract}

Keywords: virtual reality, VR, BIM, hospital, healthcare, participatory design, participation, architecture 